\title{
Respekt og kompromis - en forelæsning
}

Christian F. Rostbøll

Professor (MSO), Institut for Statskundskab, Københavns Universitet

Følgende tekst er en oversættelse og lettere revideret udgave af Christian F. Rostbølls tiltrædelsesforelæsning som professor (mso), afholdt på Institut for Statskundskab, Københavns Universitet, d. 24. april, 2015 . $^{1}$

\section{Indledning}

For godt 20 år siden begyndte jeg at læse Statskundskab. Jeg valgte studiet på grund af en passion for politik. En passion for at bekæmpe uretfærdighed. (En grund til at læse Statskundskab, som deles af i hvert fald nogle af vores studerende; hvor mange af mine kolleger der har den samme motivation, ved jeg ikke).

Hvor min første passion var politik, partisk politik, var min anden passion politisk teori og filosofi. Denne passion var forbundet med den første passion for at bekæmpe uretfærdighed, men inkluderede også en entusiasme for logik, præcision i sprogbrug og begreber - en begejstring for konsistens og logiske og præcise argumenter.

De to ting jeg lige har nævnt, passion og logik, er præcis, hvad kompromis ikke handler om. Som filosoffen George Santyana påpegede, er kompromis „odious to passionate natures because it seems a surrender, and to intellectual natures because it seems a confusion " (citeret i Gutmann og Thompson 2012, 36). Ligeledes bemærkede historikeren og politikeren T.B. Macaulay: „Logic admits of no compromise. The essence of politics is compromise. It is therefore not strange that some of the most important and most useful political instruments in the world should be among the most illogical compositions that ever were penned" (citeret i Bellamy 1999, 222, n1).

Både passionen for retfærdighed og meget af den politiske teoris optagethed af logisk og konsistent argumentation forenes i stræben efter idealet, efter det bedste. Men politik generelt og kompromisser i særdeleshed handler ikke om det ideelle. Som Otto von Bismarck skulle have sagt: „Politics is the art of the possible, the attainable the art of the next best."

At gå på kompromis betyder at få mindre eller at få noget andet, end det man foretrækker eller synes er retfærdigt. Hvornår og hvorfor bør man acceptere sådanne ringere udfald? Hvem går ind i politik for at gå på kompromis?

Kompromis var heller ikke på min dagsorden, da jeg først begyndte at studere politisk teori. Men alligevel forsker jeg nu i kompromiser. Hvorfor? Svaret på dette spørgsmål vedrører tre forbundne bekymringer og overbevisninger:

1. Uenighed er en omstændighed ved politik. Politik handler om at komme overens på trods af uenighed (Waldron 1999).

2. Respekt for alles personers lige status er en kernenorm.

3. Kompromiser er allestedsnærværende i faktisk politik.

De spørgsmål, jeg vil diskutere i denne forelæsning, er: Er kompromisvillighed en fundamental demokratisk dyd (eller blot en pragmatisk nødvendighed)? Kræver normen om lige respekt, at der indgås kompromiser i politik? Hvis et flertal kan nås uden at gå på kompromis, er der så nogen demokratiske grunde til at indgå kompromis?

\section{Betydningen af kompromis}

I politisk teori er definitioner essentielle. Det er afgørende at påpege, at jeg med kompromis mener noget meget specifikt (ikke bare hvilken som helst aftale eller forlig). Jeg definerer kompromis som en aftale, hvor alle parter giver indrømmelser for at opnå en forbedring i forhold til status quo, og hvor disse indrømmelser er motiveret af eksistensen af uenighed (Gutmann og Thompson 2012, 10; Margalit 2010, 20; May 2011, 583). Læg for det første 
mærke til, at kompromis kræver gensidige indrømmelser, ikke overgivelse, ikke blot lutter indrømmelser og ingen gevinst. For det andet er det vigtigt at notere, at kompromis er forskelligt fra konsensus: Hver part bliver ved med at foretrække et andet udfald.

I Danmark har vi et ideal om samarbejde i politik: Det samarbejdende folkestyre. Danmark ses som et konsensusdemokrati, og dette indebærer blandt andet kompromisvillighed. Denne beskrivelse findes hos både politikere og forskere. F.eks. udtalte Helle Thorning-Schmidt, før hun blev statsminister, følgende:

„Danmark er kendetegnet ved vores stærke tradition for, at der er brede flertal bag de store beslutninger. (...) En moderne politiker skal være villig til at lytte til andre og vise den ydmyghed, at også han eller hun kan blive klogere. Argumentets kraft er den største kraft i et sundt demokrati“ (Reddington 2007).

Vores statsminister ${ }^{2}$ husker sin Habermas, der talte om det gode arguments tvangsløse tvang! Eller Hal Koch, der også talte om vigtigheden af læring igennem dialog (Koch 1991, 23-25). Der er dog en vigtig forskel mellem konsensus og kompromis, der bliver overset i denne beskrivelse af dansk politik. Konsensus eliminerer uenigheden gennem dialog, hvor det stærkeste argument vinder. Her er fokus på ydmyghed, fejlbarlighed og læring. I modsætning hertil gør kompromis ikke op med uenigheden, men inkorporerer den. Her er fokus på uenighed og samfundets pluralitet. Man kan således gå på kompromis uden gensidig læring og forståelse. Der er en forskel på at være motiveret af det bedre arguments tvangsløse tvang og at være motiveret af tilstedeværelsen af uenighed.

Habermas og Hal Koch er ikke så meget interesserede i værdien af kompromis som i værdien af at lære af andre og at finde det sande fælles bedste, eller hvad Rousseau kaldte almenviljen.

Min interesse ligger i den demokratiske værdi af kompromis som en form for aftale, der inkorporerer uenighed og ikke handler om læring, der fjerner uenighed. Med denne begrebsafklaring på plads kan vi bedre forstå, hvad det er for et spørgsmål, jeg studerer.

Spørgsmålet er, hvorvidt den respekt, vi skylder vores medborgere, kan opnås blot ved flertalsbeslutninger, eller om den også kræver kompromiser: Er demokratiske kompromiser blot en uheldig nødvendighed i politik, fordi borgere og lovgivere ikke kan opnå konsensus? Har flertallet nogen demokratiske grunde til at give indrømmelser til mindretallet, hvis det kan træffe beslutninger på egen hånd? Kort sagt, har kompromiser en demokratisk værdi i sig selv?
Disse spørgsmål vedrører ikke, hvorvidt kompromiser faktisk forekommer eller er nødvendige for velfungerende demokratisk politik. Ingen vil betvivle det sidste, dvs. ingen benægter, at der er pragmatiske grunde til at gå på kompromis. Spørgsmålet er, om der er noget $i$ selve det demokratiske ideal, der gør kompromis til et demokratisk imperativ og ikke blot et nødvendigt onde.

I et studie af forlig i dansk politik konkluderer Flemming Juul Christiansen, at det er „en misforståelse at opfatte dansk politik ... som præget af særligt høje idealer om inddragelse af flest mulige interesser i den førte politik ... Partierne samarbejder, fordi det er den eneste måde at opfylde en flertalsregel på og dermed skabe resultater på “ (Christiansen 2008, 137).

Da Anders Fogh Rasmussens regering blev kritiseret for partiskhed eller 'blokpolitik', forsøgte nogle forskere i Statskundskab at gøre, hvad de kunne, for at modbevise, at dette skulle være tilfældet: „Rygterne om 'det samarbejdende folkestyres' død er stærkt overdrevne. 'Blokpolitik' og 'snævre flertal' kan måske forekomme i enkelte tilfælde, men det er ikke kendetegnende - hverken for denne regering [VK 2001-05] eller under flertallet af dens forgængere" (Kurrild-Klitgaard et al. 2005, 8).

I en skelsættende artikel om kompromiser har Simon May argumenteret for, at „compromise in political life is only ever warranted for pragmatic reasons“ (May 2005, 317). May mener, at en "policy is not more democratic because it emerges as a moral compromise between opposing parties if this also means that it diverges from the fair and just policy that a majority has voted for after public deliberations in which all parties were accommodated" (May 2005, 343). Ifølge May gælder det, at hvis alle er inkluderet i processen, der leder op til flertalsafstemningen, så tilføjer kompromiset ikke demokratisk legitimitet til beslutningen. Kompromiser kan være pragmatisk nødvendige for at opnå en aftale og lave politik, ifølge May, men de har ikke nogen værdi i sig selv.

Christiansen antyder, at der måske er et ideal om kompromis, men at det ikke er det, der motiverer danske politikere til at lave kompromiser. Simon May benægter, at kompromis er et ideal. Mit ærinde er at diskutere det sidste, dvs. om kompromis overhovedet er et ideal.

\section{To cases}

I den virkelige verdens politik er det en kendsgerning, at kompromiser ofte indgås, og at politiske aktører ofte spørger sig selv, hvorvidt de bør indgå kompromis omkring bestemte politikområder og med bestemte politiske modstandere. Lad mig nævne to cases, der illustrerer vanskeligheden ved spørgsmålet om den demokratiske værdi af kompromis. 
En case, der giver stof til eftertanke om kompromiser, er det seneste svenske valg. Efter valget d. 14. september 2014 viste de andre partier i Riksdagen, hvad man kunne kalde en kompromisløs attitude over for Sverigedemokraterna, der havde opnået $12,9 \%$ af stemmerne. Mange kommentatorer i Danmark synes, at denne attitude hos størstedelen af den svenske politiske elite var et demokratisk problem, og at man skulle indgå kompromiser med Sverigedemokraterna, som det er sket med Dansk Folkeparti i Danmark. I 1999 ytrede Poul Nyrup Rasmussen de berømte ord om Dansk Folkeparti, at stuerene bliver de aldrig, men kun to år senere indgik regeringen under ledelse af Anders Fogh Rasmussen i mange kompromiser med det højre-nationale parti.

Et spørgsmål er, om den kompromisløse attitude over for Sverigedemokraterna var ikke blot strategisk dum, men også udemokratisk. Denne case rejser interessante spørgsmål om kompromisets demokratiske status og grænserne for kompromis.

En anden case, der interesserer mig, er debatten om ytringsfrihed og respekt for forskellighed (noget, jeg tidligere har skrevet om, men ikke tidligere i forhold til kompromis; Rostbøll 2007; 2009; 2010; 2011a). Ytringsfriheden har, siden kontroverserne om Muhammadtegningerne begyndte i 2005, været genstand for intens debat. Nogle mener, at Danmark bør stå fast på ytringsfrihed. Andre kræver respekt for forskellighed og uenighed. Bør vi i Danmark gå på kompromis med ytringsfriheden, blot fordi nogle medlemmer af vores samfund er uenige i dens absolutte værdi?

Den anden case er selvfølgelig forskellig og mere hypotetisk, da der ikke eksisterer noget politisk parti i Danmark, der rent faktisk vil begrænse retten til ytringsfrihed. Mit spørgsmål drejer sig om det hypotetiske tilfælde, hvor sådan et parti eksisterede og blev valgt til Folketinget.

Jeg har valgt disse to forskellige cases, fordi forskellige personer, afhængig af deres politiske holdninger, vil tendere mod at være enige i værdien af at gå på kompromis med Sverigedemokraterna versus at gå på kompromis med f.eks. ytringsfriheden i forhold til muslimers krav om respekt. Men fra et demokratisk perspektiv bør værdien af kompromis ikke været bestemt af ens politiske position bortset fra ens tilslutning til demokrati. For at slå det fast er mit spørgsmål, hvorvidt tilslutning til demokrati kræver kompromisvillighed - og over for hvem.

Disse to eksempler viser vanskeligheden ved kompromiser: Var det udemokratisk af de andre partier ikke at ville indgå kompromis med Sverigedemokraterna? Kræver vores demokratiske principper, at vi går på kompromis med ytringsfriheden?

Jeg nævner disse to cases for at illustrere både relevansen og vanskeligheden ved spørgsmålet om kompromiser.
Hvis kompromisvillighed anses som en grundlæggende demokratisk dyd, synes det at følge, at de svenske partier bør gå på kompromis med Sverigedemokraterna og måske også, at vi i Danmark bør finde et kompromis med hensyn til ytringsfriheden. Men mange vil have svært at ved at acceptere disse konklusioner. Er det, fordi vi ikke er demokrater alligevel, eller fordi demokrati ikke kræver kompromisvillighed?

Jeg vil ikke svare direkte på disse spørgsmål i forhold til de to cases. Dette kræver en meget mere detaljeret fremstilling og analyse af de to cases, end jeg kan give her. Derudover er jeg ikke sikker på, at det er politisk teoris opgave at besvare sådanne spørgsmål.

\section{Vanskeligheden ved demokrati, tolerance og kompromis}

De to cases viser, at det sommetider er vanskeligt at være demokrat. Som demokratiske borgere bliver vi nogle gange nødt til at acceptere beslutninger, love og politikker, som vi synes er uretfærdige og ukloge, fordi andre borgere eller deres repræsentanter har stemt for dem. Og sommetider bliver de repræsentanter, vi har valgt, nødt til at samarbejde og gå på kompromis med andre repræsentanter, som vi synes tager fejl, er dumme, umoralske eller ligefrem onde.

Læg mærke til, at jeg som demokrat ikke bare skal adlyde en lov, som er bestemt gennem den demokratiske procedure, men også finde den legitim. Dette er i hvert fald tilfældet, hvis det at være demokrat betyder, at man mener, at den demokratiske procedure skaber legitimitet. Hvorfor skal man acceptere en lov eller politik, som man mener er uretfærdig og/eller uklog, som legitim?

Det er blevet foreslået, at kompromis minder om tolerance, fordi begge består i „enighed om at være uenige“ (Bellamy et al. 2012, 281). Vi kan dermed sammenligne vanskeligheden ved at være demokrat med vanskeligheden ved tolerance.

For at forstå vanskeligheden ved tolerance er det vigtigt at påpege, at tolerance kun er en relevant attitude over for holdninger og handlinger, som vi afviser, afskyr, eller finder forkerte. Vi taler kun om at tolerere holdninger og handlinger, som vi afviser, ikke alle holdninger og handlinger som vi ikke kan lide. Jeg synes måske boksning er kedeligt, men vi siger ikke, at jeg tolererer din kærlighed til boksning. Vanskeligheden ved tolerance ligger i, at tolerance på en og samme tid indebærer afvisning og accept af andres synspunkter og handlinger.

Kompromis i politik er dog mere krævende end tolerance, som dette normalt forstås i politisk teori. Tag f.eks. John Stuart Mills forståelse af tolerance. Mill skriver, at vi skal lade andre mennesker leve, som de vil, bare de ikke skader andre, selv hvis vi finder deres handlinger „foo- 
lish, perverse or wrong" (Mill 1989, 15). Men kompromis handler ikke blot om at være enige om at være uenige om individuelle private synspunkter (f.eks. religion); det handler om at acceptere, at vores uenigheder materialiseres i fælles love, der håndhæves med tvang. Når et politisk parti indgår et kompromis med et andet politisk parti, tolererer det ikke blot dette partis eksistens; det tilpasser eller inkluderer dets synspunkter i lovgivning, der regulerer alle borgeres adfærd.

Nogle mener, at tolerance er en form for relativisme, og at demokrati bedst kan forsvares på grundlag af værdirelativisme. Men dette er en stor fejltagelse. Værdirelativisme kan ikke forklare værdien af hverken demokrati, tolerance, kompromis, eller værdien af noget overhovedet. Det følger ikke af, at der ikke er noget korrekt svar på normative spørgsmål, at alle bør have lige indflydelse. Vi kunne ligeså godt sige, at hvis vi ikke kan vide, hvem der har ret, så bør jeg bestemme, eller den stærkeste bestemme, eller afgøre spørgsmålet ved plat og krone eller gøre ingenting.

Man kan argumentere for både tolerance og demokrati på grundlag af uenighed, men for at komme fra uenighed til tolerance og demokrati er der brug for en normativ præmis.

\section{Gensidig respekt}

Den normative præmis, som jeg foreslår, er gensidig og lige respekt eller gensidig respekt for andre som ligeværdige. Både demokrati og tolerance er baseret på en norm om respekt for andres holdninger. Demokrati indebærer, at vi respekterer, at vores medborgeres holdninger bør gives samme vægt som vores egne i den demokratiske proces.

Der er en udbredt enighed blandt politiske teoretikere om, at demokrati er retfærdiggjort, fordi det respekterer borgernes lighed. Som Thomas Christiano skriver, er demokrati "a publicly clear way of recognizing and affirming the equality of citizens" (Christiano 2008, 96). Den lige stemmeret, lighed i muligheder for stille op til politiske embeder og lige muligheder for deltagelse i forhandling og diskussion er alle måder at behandle borgere som ligeværdige. Også den demokratiske flertalsregel kan begrundes med en norm om lige respekt:

„[M]ajority-decision respects the individuals whose votes it aggregates. It does so in two ways. First, it respects the differences of opinion about justice and the common good ... Second, it embodies a principle of respect for each person in the processes by which we settle on a view to be adopted as ours even in the face of disagreement" (Waldron 1999, 109).
Både Christiano og Waldron forsvarer gængse demokratiske procedure på grundlag af en norm om lige respekt. Kan kompromis forsvares på samme vis?

I litteraturen om kompromis bliver normen om lige og gensidig respekt set som det moralske grundlag for kompromis. For eksempel mener Colin Bird, at „... we ought to compromise because doing so is the appropriate way to display respect to citizens with a variety of views about the relevant public policy issue. The imperative to compromise thus derives from the moral norm of mutual respect, not from a prudential calculation" (Bird 1996, 92). Bird argumenterer således for, at kompromis er et ideal og ikke blot en pragmatisk nødvendighed - og at det er et ideal, der kan udledes fra den fundamentale norm om gensidig respekt.

\section{Respekt for borgere som hvad?}

Husk, at mit spørgsmål er, hvorvidt vores demokratiske idealer kraver kompromis. Jeg har udpeget respekt for lighed som et demokratisk kerneprincip på grund af dets fremtrædende position i den normative litteratur om både retfærdiggørelsen af demokrati og om kompromis. Men forståelsen af respekt for lighed i den eksisterende litteratur er utilfredsstillende eller underspecificeret. For at komme tættere på et svar på spørgsmålet om, hvorvidt respekt for lighed kræver kompromis, er det nødvendigt med en begrebsafklaring af denne idé og mere specifikt en analyse af idéen om demokratisk respekt.

Simon May (som jeg tidligere har refereret til) argumenterer for, at "there are many ways to express respect without resorting to compromise" (May 2005). F.eks. ved lige stemmeret og ved at lytte til og argumentere med andre. Det er sandt, hvad May siger, men mit spørgsmål er, hvorvidt disse andre måder at udvise respekt over for ens politiske modstandere er tilstrækkelige for demokratisk respekt. Når vi er interesserede i demokratiske grunde til at indgå kompromis, kan vi ikke være tilfredse med, at den politiske proces udviser respekt for borgere $\mathrm{i}$ en eller anden generel forstand. Jeg udviser f.eks. respekt for andre politiske teoretikere ved at lytte til og svare på deres argumenter, men dette er ikke det samme som demokratisk respekt. Demokratisk respekt er speciel, og hvad det indebærer, kan ikke forklares ud fra en generel idé om, hvad det vil sige at respektere andre.

Der findes to prominente forståelser af respekt i litteraturen om demokrati og kompromis, men begge er mangelfulde - af forskellige grunde: Den ene siger kort og godt, at kompromis respekterer borgernes lighed. Den anden siger, at kompromis respektere andre som medlemmer af samme fallesskab. Som medlemmer af det samme fællesskab bør vi udvise andre en basal respekt, der inkluderer „a willingness to make the ends of other members of the 
group one's own“ og en afvisning af et „'winner-takes-all' society" (Weinstock 2013, 543, 552). Weinstocks argument er, at det er en specifik forståelse af fællesskab, der forklarer værdien af kompromis - eller hvorfor kompromis ikke blot er en pragmatisk nødvendighed men et ideal.

Lad mig forklarer svaghederne ved hver af disse to forståelser. Problemet med forsvaret for kompromis, der hviler på respekt for andre som lige, er, at ikke kun demokratiske procedurer tilfredsstiller en norm om ligebehandling: Lodtrækning eller plat/krone behandler og respekterer også de involverede parter som lige. Derfor kan respekt for lighed, forstået generisk eller minimalt, ikke forklarer den moralske vigtighed af demokrati eller kompromis (Estlund 2008: kap. 4; Rostbøll 2015a). Selv hvis ligebehandling er nødvendigt for, at en institution kan kaldes demokratisk, er det stadig ikke tilstrækkeligt. Idéen om ligebehandling eller lige respekt forklarer ikke værdien eller behovet for kompromis, men det forklarer heller ikke behovet for valg, lydhørhed, osv., som vi opfatter som værende centrale for repræsentativt demokrati.

Der er flere problemer med forsvaret for kompromis, der hviler på en specifik forståelse af fællesskab. Idéen om fællesskab er ikke „fully endogenous to a concept of democracy“ (Beerbohm 2014, 25). Med andre ord, værdien af fællesskab er ikke iboende demokratisk, dvs. påkaldelsen af fællesskab lokaliserer værdien af demokrati uden for selve begrebet om demokrati eller prøver at reducere det til en anden værdi. Hvis familien eller venskab er eksempler på fællesskab, så kan denne værdi realiseres uden demokrati. Påkaldelsen af fællesskab hviler på en kontroversiel forståelse af, hvad en stat er. Det er problematisk at se et politisk fællesskab på lige fod med en familie, hvor man deler ansvar for mål (May 2011). Grundene til kompromis blandt ægtefæller og blandt venner er ikke de samme som for fremmede i et politisk fællesskab.

Fællesskab kan forklare vigtigheden af kompromis på en måde, som lige behandling ikke kan, men kun ved at importere en værdi, som ligger uden for selve begrebet om demokrati - og det formår ikke at identificere forskellen mellem grunde til at indgå kompromisser med ægtefæller eller venner og grunde til at indgå kompromisser i politik.

\section{Respekt for andre som med-lovgivere}

Hvis problemet med respekt for lighed og den respekt, der er del af at se andre som medlemmer af samme fællesskab, er, at de enten er utilstrækkelige eller eksterne i forhold til begrebet om demokrati, virker det åbenlyst at se på en idé, der er en indiskutabelt del af demokrati: Idéen om kollektivt selvstyre. Denne idé går videre end respekt for lighed til respekt for alles frihed eller autonomi, hvilket kræver mere end en lodtrækning, snarere den type lydhørhed involveret i demokratiske procedurer, som vi kender dem (Rostbøll 2015a). Og i kontrast til idéen om demokratisk fællesskab er kollektivt selvstyre endogent $\mathrm{i}$ forhold til begrebet demokrati.

Mange teoretikere er dog mistænkelige overfor idéen om, at demokrati rent faktisk realiserer kollektivt selvstyre. Fra John Stuart Mill og frem har de påpeget, at argumentet for, at det at adlyde folkets vilje er det samme som at adlyde én selv, ikke er overbevisende:

„The 'people' who exercise the power are not always the same people as those over whom power is exercised; and the 'self-government' spoken of is not the government of each by himself, but of each by all the rest" (Mill 1989, 7-8).

Problemet opstår især, når kollektivet opfattes på en måde, der ikke respekterer samfundets pluralitet eller diversitet. Det vil sige, når der ikke bliver udvist respekt for individets unikke synspunkter, men kun for 'folket' som et kollektiv. Mange ser dette særligt som et problem hos Rousseau (Rostbøll 2015b).

Kritikken af demokrati som selvstyre kan også være baseret på det synspunkt, at demokrati kan reduceres til flertalsstyre, som for eksempel Allen Buchanan (2003, 17-18): „[I]t is simply false to say that an individual who participates in a democratic decision-making process is self-governing; he or she is governed by the majority."

Således er Mills indvending rettet mod den Rousseauske idé om almenviljen, mens Buchanan opfatter demokrati som flertalsstyre og ikke andet. Mit forslag er, at hvis vi ud over flertalsstyre også opfatter kompromisser som en essentiel del af den demokratiske proces, så kan vi (i hvert fald til en vis grad) imødegå indvendingerne mod idéen om demokrati som realisering af selvstyre.

Kompromis foregiver ikke at repræsentere en Rousseausk fællesvilje og kan heller ikke reduceres til flertalsprincippet. Kompromis respekterer borgere som deltagere i selvstyre på tre måder: For det første kræver kompromis ikke, at vi ser 'folket' som en udifferentieret kollektiv vilje. Som nævnt tidligere tager kompromis udgangspunkt i uenighed og respekt for samfundets pluralitet. Som Gutmann og Thompson formulerer det, „... the disagreements among the parties are embodied in the compromise itself" (Gutmann og Thompson 2012, 12). Kompromis bør ses i kontrast til Rousseaus almenvilje, der, som Hannah Arendt formulerede det, „bound the many into one“ (Arendt 1990, 77).

For det andet er dette ikke baseret på, at vi bør værdsætte diversitet som sådan, men at vi bør respektere borgere som „self-authenticating sources of valid claims“ (Rawls 1993, 32). Det vil sige, at vi respekterer medbor- 
gere som værende i stand til at danne politiske holdninger med en vis grad af validitet. Alles holdninger bør gives en vis vægt, uafhængig af deres indhold.

For det tredje bringer kompromis os tættere på idealet om at respektere alle som deltagere i selvstyre, end deliberation og stemmeafgivning gør. Læg mærke til, at jeg ikke påstår, at idealet er, at borgere skal være kollektivt selvlovgivende forstået således, at alle kan få, hvad de foretrækker. Idealet er, at alle kan deltage i selvlovgivning (Rostbøll 2008, 104f). Og mit forslag er, at kompromis kan bidrage til at komme tættere på idealet om, at alle er deltagere i kollektivt selvstyre end blot og bart flertalsstyre.

Tilsammen udgør ovenstående en principiel og demokratisk grund til kompromis.

\section{Grænser for kompromis}

Det foregående argument viser, at der er principielle grunde for kompromis, der hviler på et ideal om demokratisk respekt. Men indebærer det også, at kompromis bør gives samme moralske status som retten til at stemme og til at deltage i offentlig debat? Det mener jeg ikke og vil her i den sidste del af min forelæsning forklare hvorfor ikke. I mit nuværende forskningsprojektet har jeg en længere diskussion af dette spørgsmål, men her må jeg nøjes med at give en kortere version.

Retten til at sige ens mening, til at deltage i offentlig deliberation og til at stemme ved valg er noget, alle borgere har alene af den grund, at de er borgere. Hvis en borger nægtes retten til at stemme, kan borgeren klage over, at hun ikke er blevet anerkendt for, hvad hun er: En borger.

Tingene ser anderledes ud, når vi går fra repræsentation i den politiske proces til repræsentation i udfald. Det ville være underligt ikke at evaluere ens modstanders holdninger, når man overvejer, hvorvidt man skal indgå kompromis med hende. Der er ingen (tror jeg), der mener, at vi skal gå på kompromis med alle og enhver af vores politiske modstandere bare fordi, de er vores medborgere eller medlovgivere. En vis positiv vurdering af den anden er involveret, når vi går på kompromis med andre. Som minimum må vi antage, at modstanderen indgår kompromiset i den rette ånd, og at hun ikke prøver at manipulere eller snyde os.

Alle politiske teoretikere, der skriver om kompromis, er enige om, at kompromis kun er værdifuldt under bestemte omstændigheder. Som Avishai Margalit (2010) formulerer det, er nogle kompromiser ,rotten compromises". Der er uenighed om præcis, hvad der gør et kompromis råddent eller uacceptabelt, men det virker som et absurd synspunkt at hævde, at kompromiser, der tilgodeser et hvilket som helst synspunkt, er værdifulde.

\section{Konklusion}

Jeg håber at have vist, at man kan beskæftige sig med kompromis med en passion for idealer og med konsistens og logik. At studere kompromiser indebærer ikke at gå på kompromis med ens egne forskningsstandarder.

Det spørgsmål, jeg har rejst i denne forelæsning, er, hvilken demokratisk betydning vi bør tillægge kompromiser. Er demokratiske kompromiser blot en uheldig nødvendighed i politik, fordi borgere og lovgivere ikke kan opnå konsensus? Har flertal nogen demokratiske grunde til at give indrømmelser til mindretal, hvis de kan træffe beslutninger på egen hånd? Kort sagt, har kompromis i sig selv demokratisk værdi?

Jeg har udforsket disse spørgsmål ved at fokusere på spørgsmålet om, hvad der menes med og kræves af idéen om demokratisk respekt. Jeg har argumenteret for, at demokratisk respekt bør forstås som en form for anerkendelse af ens medborgere som medlovgivere.

Min konklusion er: Der er ikke-pragmatiske demokratiske grunde til at gå på kompromis, og disse grunde er baseret på respekt for medborgere som medlovgivere. Dog indebærer denne konklusion ikke, at kompromiser har samme moralske vigtighed og status i et demokrati som retten til at deltage i deliberation og stemmeafgivning. Kompromiser kan gøre beslutninger mere demokratiske, men kun under bestemte omstændigheder.

Kompromis er et ideal, fordi det virkeliggør respekt for forskellighed og udviser respekt for borgere som medlovgivere. Kompromis er et ideal i sig selv, hvis det faktum, at der indgås et kompromis - uafhængigt at konsekvenserne ved dette kompromis - giver udfaldet legitimitet. Kompromis er et ideal, hvis vi skylder vores politiske modstandere indrømmelser, selvom vi ikke føler os overbeviste af deres synspunkters rigtighed.

Men vi er ikke påkrævet at indgå kompromis med hvem som helst. Nogle kompromiser underminerer selve idealet, der forklarer, hvorfor vi overhovedet bør gå på kompromis. Desuden giver vi andre legitimitet ved at indgå kompromiser med dem - og der er grænser for, hvilke politiske modstandere vi bør give legitimitet.

Hvis vores fundamentale forpligtelse er demokratisk respekt, så går grænsen for kompromis ved kompromiser med personer, der ikke accepterer normen om demokratisk respekt. Hvorvidt kompromis med f.eks. Sverigedemokraterna eller omkring ytringsfrihed underminerer demokratisk respekt eller er krævet af det, vil jeg overlade til jer at overveje. Opgaven for politisk teori er ikke at gøre offentlig debat unødvendig, men at bidrage til den (Rostbøll 2011b). 


\section{Litteratur}

Arendt, H 1990, On Revolution, Penguin, Harmondsworth

Beerbohm, E 2014, 'The Problem of Clean Hands: Legislative Compromise and Obstructionism', paper presented at the conference of the American Society for Political and Legal Philosophy, Chicago, January 2014.

Bellamy, R 1999, Liberalism and Pluralism: Towards a Politics of Compromise, Routledge, New York.

Bellamy, R, Kornprobst, M \& Reh, C 2012, 'Introduction: Meeting in the Middle', Government and Opposition, vol. 47, no. 3, pp. 275-295.

Bird, C 1996, 'Mutual Respect and Neutral Justification', Ethics, vol. 107, no. 1, pp. 62-96.

Buchanan, A 2003, 'Democracy and Secession', In National Self-Determination and Secession, ed. Margaret Moore, Oxford Scholarship Online.

Christiano, T 2008, The Constitution of Equality: Democratic Authority and Its Limits, University Press, Oxford.

Christiansen, FJ 2008, Politisk forlig i Folketinget: Partikonkurrence og samarbejde, Politica, Aarhus.

Estlund, D 2008, Democratic Authority: A Philosophical Framework, University Press, Princeton.

Gutmann, A \& Thompson, D 2012, The Spirit of Compromise: Why Governing Demands It and Campaigning Undermines It, Princeton University Press, Princeton.

Koch, H 1991, Hvad er demokrati?, Gyldendal, København.

Kurrild-Klitgaard, P, Klemmensen, R \& Hansen, ME 2005, 'Blokpolitik og det „samarbejdende folkestyres“ fire gamle partier, 19532005', Politologiske Skrifter, no. 2.

Margalit, A 2010, On Compromise and Rotten Compromises, Princeton University Press, Princeton.

May, SC 2005, 'Principled Compromise and the Abortion Controversy', Philosophy and Public Affairs, vol. 33, no. 4, 2005, pp. 317-48.

May, SC 2011, 'Moral Compromise, Civic Friendship, and Political Reconciliation', Critical Review of International Social and Political Philosophy, vol. 14, no. 5, pp. 581-602.

Mill, JS 1989, On Liberty and Other Writings, Cambridge University Press, Cambridge.

Rawls, J 1993, Political Liberalism, Columbia University Press, New York.
Reddington, N 2007, Den Forste: En samtalebog med Helle ThorningSchmidt, Art People.

Rostbøll, CF 2007, 'Ytringsfrihed, respekt og ansvar', Tidsskriftet Politik, vol. 10, no. 4, pp. 76-85.

Rostbøll, CF 2008, Deliberative Freedom: Deliberative Democracy as Critical Theory, State University of New York Press, Albany.

Rostbøll, CF 2009, 'Autonomy, Respect, and Arrogance in the Danish Cartoon Controversy', Political Theory, vol. 37, no. 5, October, pp. 623-648.

Rostbøll, CF 2010, 'The Use and Abuse of 'Universal Values' in the Danish Cartoon Controversy', European Political Science Review, vol. 2, no. 3, pp. 401-422.

Rostbøll, CF 2011a, 'Freedom of Expression, Deliberation, Autonomy, and Respect', European Journal of Political Theory, vol. 10, no. 1, pp. 5-21.

Rostbøll, CF 2011b, 'Politisk teori og god statskundskab', Politica, vol. 43, no. 1, pp. 110-128.

Rostbøll, CF 2015a, 'The Non-Instrumental Value of Democracy: The Freedom Argument', Constellations, vol. 22, no. 2, pp. 267-278.

Rostbøll, CF 2015b, 'Non-domination and Democratic Legitimacy', Critical Review of International Social and Political Philosophy, vol. 18, no. 4, pp. 424-439.

Waldron, J 1999, Law and Disagreement, Oxford University Press, New York.

Weinstock, D 2013, 'On the Possibility of Principled Moral Compromise', Critical Review of International Social and Political Philosophy, vol. 16, no. 4, pp. 537-556.

\section{Noter}

1. Troels Skadhauge har stået for oversættelsen af den engelske tekst til forelæsningen. Oversættelsen er derefter gennemskrevet af Christian Rostbøll. Forelæsningsstillen er bibeholdt frem for at omskrive teksten til en egentlig artikel.

2. Thorning-Schmidt var statsminister, da denne forelæsning blev afholdt. 